\title{
中高年者の長距離走前後の血圧及び心電図の変動について
}

$\begin{array}{llllllll}\text { 小 原 達 朗* } & \text { 小 新 吉** 浅 野 勝 己** } \\ \text { 古 田 善 伯** 藤 牧 利 昭**** 矢 野 徳 郎** } \\ \text { 富 原 正 二***** }\end{array}$

\section{CHANGES IN BLOOD PRESSURE AND ECG BETWEEN BEFORE AND AFTER LONG DISTANCE RUNNING IN MIDDLE-AGED AND OLD RUNNERS}

\author{
Tatsuro Obara, Shinkichi Ogawa, Katsumi Asano, Yoshinori furuta, \\ Toshiaki Fujimaki, Tokuo Yano and Masaji Tomihara
}

\begin{abstract}
In order to elucidate the changes of cardiovascular functions on the long distance running in middle-aged and old men (aged 40-87 years) performing the running training at least over a year measured on blood pressure and ECG before and after the $10 \mathrm{~km}, 25 \mathrm{~km}$ and $42 \mathrm{~km}$ running, respectively. Furthermore, several runners fainted during and at the end of running were also measured on the blood pressure at the fainting. The results were summarized as follows,

In the $10 \mathrm{~km}, 25 \mathrm{~km}$ and $42 \mathrm{~km}$ running the average values of systolic (excepting the $10 \mathrm{~km}$ ), and diastolic pressure after running were significantly lower than those average values before running. Further, it was noted that the higher the systolic and diastolic pressure before running were the more the reduction of those blood pressure after running in any distance, and also with the prolongation of running distance the reduction of those blood pressure became more remarkable. Especially, the reduction of blood pressure in the fainted runners was very remarkable. On the other hand, the pulse pressure showed no significant difference between before and after running.

On the observation of ECG recorded before and after running, the shortening of $P Q$ interval and the prolongation of QTc were noted after running, especially the prolongation of QTc in a group of $42 \mathrm{~km}$ was remarkable. While the reduction of $T_{\text {II }}$ voltage was also found after running.

It may be therefore thought that a long distance running in middle-aged and old men bring on large changes for their cardiovascular functions, even if they continued the running training over a year.
\end{abstract}

(J. Physical Fitness Japan 1981, $30: 137 \sim 147$ )

I. 緒 言

いま，わが国では，出生率の低下と枃序命の 延長による人口の老令化により, 老人笑療費の増
㞦という䦌題を抱えている。また，60才停年助代 を迎えて中高年者が学働に耐えうることが社会的 要請となっており，小高年者の健康と体力の低下 の防止:之維持・增進の期待が高まっている(14)。乙

\footnotetext{
* 辰崎大学教育学部 Faculty of Education, Nagasaki Uuiversity. Nagasaki-shi, Nagasaki-ken 852

** 筑波大学体育科兴系 Institute of Health and Sport Science, The University of Tsukuba. Ibaragi-ken 305

*** 呫皇大学教青学部 Depertment of Health and Physical Education, Faculty of Education, Gifu University. Gifu-shi, Gifu-ken 502 
のような背累にあってい高年者を対采とした持久 赴大会は，今や全国各地で実施されており，その 参加者は相当数にのぼっているものと思わ机る。 こ机らの中高年者は，長期間にわたってトレーニ ングを継続している者むあるが，中には，短期間 のトレーニングで大会に参㞦，長い趾離に挑む 者も少なくない200。

従来, 中高件者の身体トレーニングによる体 重，艾脂曆など形態あるいは呼吸循環系をい心と した種々の生理機能の改善に関する報告が数多く なされている3(2)12)19)22(26)29)30)32)。しかし，1川年閒 を超える长距離心における生理機能の变動に竖す る報告は少なく21225)，さらに，乙の種の大会に打 いて幾度か不幸な市敌が生じているにもかかわら ず，中高年起者にいかなる生理㙨能の変動を招米 するかについては，未だ十分な検討がなされてい な(23)24)

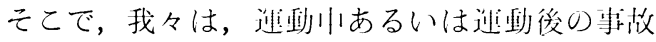
にもつながる衍橓系機能の变動に関して，特に，

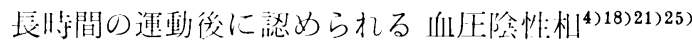
の本態を明らかにするために，1975年の第 8 回国 際问分者走大会之1976年の多禁湖マラソン大会お よび第 5 回タートルマラソン全国大会でり'実際の

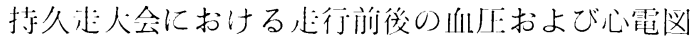
を测定した。また，第 5 同タートルマランン全国 大会においては，止行中あるいはゴール後华倒し た者の身体状洒を归らかにするために卒倒後の血 压についても测定したので併せて㭘討した。

\section{II. 研 究 方 法}

\section{1. 対象とした競技会}

・第 8 回国際高分者小大会 $(10 \mathrm{~km}, 25 \mathrm{~km})$

1975年 9 月，山梨览川中湖畔

・多摩湖マラソン大会 $(42.195 \mathrm{~km})$
1976年: 4 月，東京都多摩湖畔

・第 5 四タートルマラソン全国大会 $(10 \mathrm{~km}, 25$ $\mathrm{km}$ )

1976年 9 月，静潞県田子の浦湤岸

\section{2. 被験者}

削述の 3 競技会に参川した中から被験者の人数 は，表 1 に示すように $10 \mathrm{~km}$ 群 102 人, $25 \mathrm{~km}$ 群 95 人および $42 \mathrm{~km}$ 群 10 人で，乙れら全被験者の

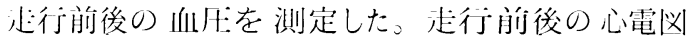
は， $10 \mathrm{~km}$ 群 4 人， $25 \mathrm{~km}$ 群 7 人および $42 \mathrm{~km}$ 群 9 人を抽出して测定した。また，起行夜後の体重 は, $10 \mathrm{~km}$ 群 10 人, $25 \mathrm{~km}$ 群 13 人および $42 \mathrm{~km}$ 碚 10 人について测定した。さらに，第 5 回タート ルマラソン全国人会においては，走行师あるいは ゴール後坐倒した者 8 人について卅倒目後の血压 を测定し，走行解侣との此較在行った。なお，被 騃者は，全员男子を刘象とした。

\section{3. 測定方法}

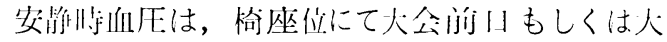
会当甘のウォーミングアップ以的に测定し，こ机

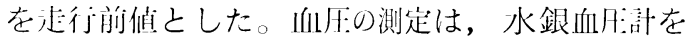
用い蚛診法により行った。ただし，第 8 回山際问 合者走大会に揖いては，こ机とパラマ社製デジタ

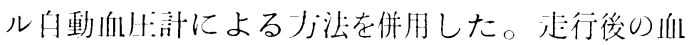

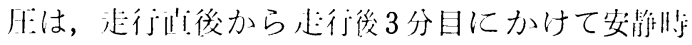
倘压と同様のノj法により测资した。

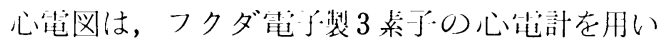

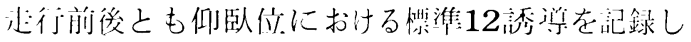
た。

处行中あるいはゴール後丛倒した者り血龙は, 決路監視中に卒倒者に遭遇した将合に等倒後直ち に测定した。

体等は，天科体亘計によりランニングパンツの みの符衣にて $10 \mathrm{~g}$ の紧位まで测定した。

Table 1. The number and age of the subjects

\begin{tabular}{|c|c|c|c|c|c|c|c|c|c|c|c|c|c|}
\hline \multirow[b]{3}{*}{$\begin{array}{c}\text { Age } \\
(\text { yrs. })\end{array}$} & \multicolumn{11}{|c|}{ Blood pressure } & \multirow{3}{*}{$\mid \frac{\mid \text { ECG }}{\mid \text { Total }}$} & \multirow{3}{*}{$\begin{array}{r}\text { Fainting } \\
\text { Total }\end{array}$} \\
\hline & \multicolumn{5}{|c|}{$10 \mathrm{~km}$} & \multicolumn{5}{|c|}{$25 \mathrm{~km}$} & \multirow{2}{*}{4} & & \\
\hline & $40-49$ & $50-59$ & $60-69$ & $70-$ & Total & $40-49$ & $50-59$ & $60-69$ & $70-$ & Total & & & \\
\hline Number & 29 & 23 & 28 & 22 & 102 & 29 & 30 & 25 & 11 & 95 & 10 & 20 & 8 \\
\hline Mean age & 44 & 55 & 65 & 76.9 & 59.1 & 45 & 54 & 64 & 73.6 & 56.2 & 56.3 & 57.5 & 54.6 \\
\hline
\end{tabular}




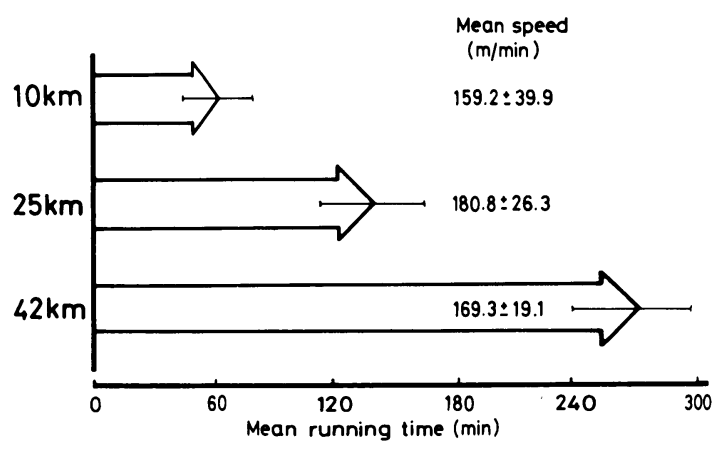

Fig. 1. Mean running time and speed on each running distance

\section{III. 結果}

1. 走行スピードについて

図 1 は, 被験者の各起行距離に打ける平均走行 スピードと斗均沂览猔間について示したものであ る。文均所要顺閒は, $10 \mathrm{~km}$ 群が $62.8 \pm 21.0$ 分, $25 \mathrm{~km}$ 群が $138.3 \pm 23.5$ 分, $42 \mathrm{~km}$ 群が $249.2 \pm$ 28.1 分であった。しかしながら, 平均スピード は，一般的には $10 \mathrm{~km}$ 群が速いと考えられるが, 本結果では, $25 \mathrm{~km}$ 群が茸も速くて $180.8 \pm 26.3$ $\mathrm{m} /$ 分, 次いで $42 \mathrm{~km}$ 群の $169.3 \pm 19.1 \mathrm{~m} /$ 分で, $10 \mathrm{~km}$ 群は $159.2 \pm 39.9 \mathrm{~m} /$ 分で最も遅かった。こ のことについては考察の项で後述する。

\section{2. 走行前後の血圧について}

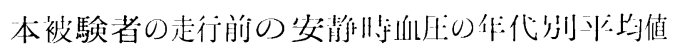
および標準偏差は，四 2 に示したように收維期血 压は，64才までは日本人头埴值 ${ }^{16)}$ とぼ同椂であ るが，65才以上では增㸬せず，むしろ40才代と同 棪の横ばい状態にあり，昖张剘血压は，日本人平 均值と同棪の倾向を示した。

汹 3 は, 各走行距離别に收縮期血圧, 昖張期血 压，平均血灰および脈压について走行前之走行後 の平均值と情準偏差の变動を示したものである。

安敖值は, $10 \mathrm{~km}$ 群之 $25 \mathrm{~km}$ 群はいずれの血压 もほぼ等しく, $42 \mathrm{~km}$ 群でやや低值を示してい る。走行後の値は, $10 \mathrm{~km}$ 群は搪張期血圧之平均 血圧において走行前に対し統計的に有意な低下を 示し，収縮期血圧と脈压は有意な変動を示さなか った。 $25 \mathrm{~km}$ 群と $42 \mathrm{~km}$ 群は, 収縮期血压, 昖艮 期血压技よび平均脰压とも走行前に刘し边行後有 意な低下を示した。脈压については，いずれつ趾 離群とも平均值はほとんど变動がみられなかっ

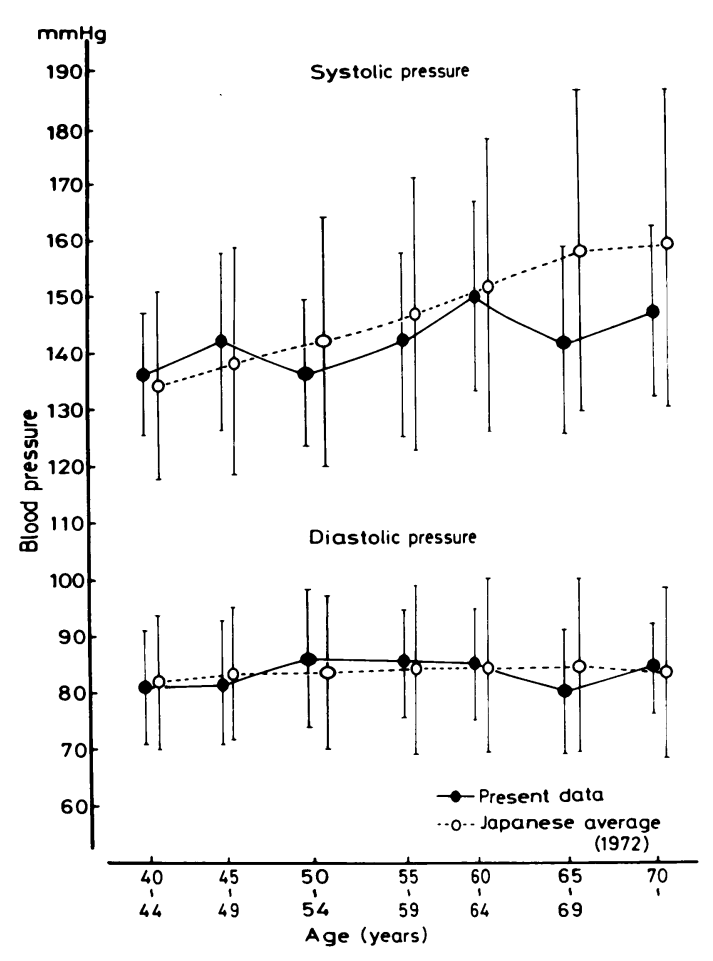

Fig. 2. Comparison of blood pressure between present data and Japanese average.

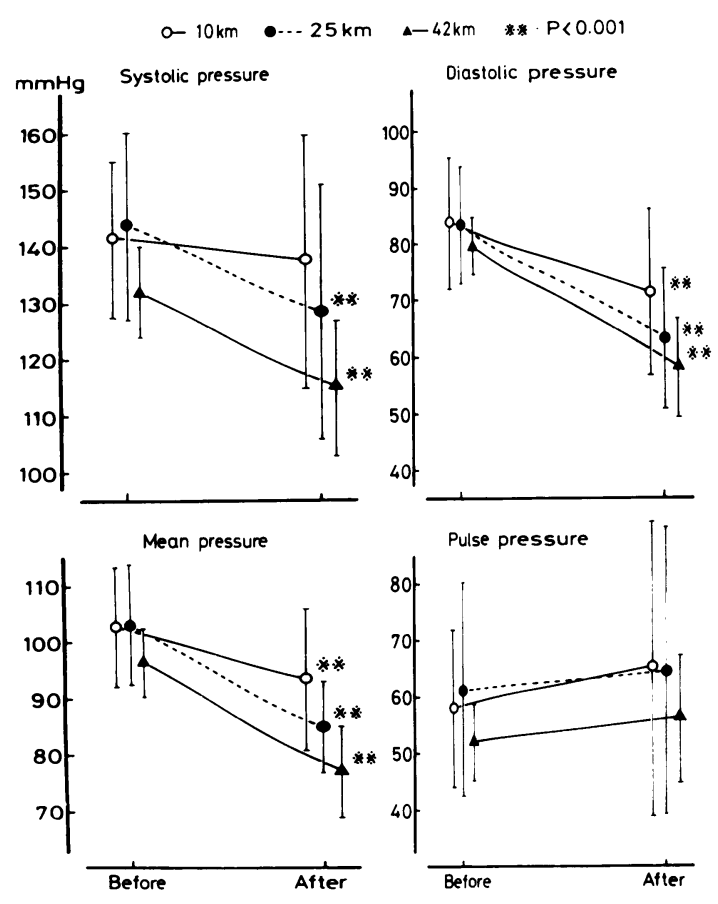

Fig. 3. Comparison of blood pressure between before and after running. 
Table 2. Correlation coefficients between age, running time and blood pressure at rest and difference of each blood pressure (Rest-After)

\begin{tabular}{|c|c|c|c|c|c|c|c|c|c|}
\hline & \multicolumn{3}{|c|}{$\Delta$ Systolic pressure } & \multicolumn{3}{|c|}{$\Delta$ Diastolic pressure } & \multicolumn{3}{|c|}{$\Delta$ Pulse pressure } \\
\hline & $10 \mathrm{~km}$ & $25 \mathrm{~km}$ & $42 \mathrm{~km}$ & $10 \mathrm{~km}$ & $25 \mathrm{~km}$ & $42 \mathrm{~km}$ & $10 \mathrm{~km}$ & $25 \mathrm{~km}$ & $42 \mathrm{~km}$ \\
\hline Age & -0.109 & -0.115 & -0.510 & 0.082 & -0.047 & 0.158 & -0.055 & -0.096 & -0.456 \\
\hline Running time & -0.209 & -0.068 & -0.448 & -0.180 & 0.072 & 0.388 & -0.279 & -0.279 & -0.750 \\
\hline $\begin{array}{l}\text { Systolic pressure } \\
\text { (Before) }\end{array}$ & $-0.277^{* *}$ & $-0.383 \mid$ & -0.676 & & & & & & \\
\hline $\begin{array}{l}\text { Diastolic pressure } \\
\text { (Before) }\end{array}$ & & & & -0.253 & $\begin{array}{r}* * * \\
-0.475\end{array}$ & -0.534 & & & \\
\hline $\begin{array}{c}\text { Pulse pressure } \\
\text { (Before) }\end{array}$ & & & & & & & -0.366 & -0.219 & $\begin{array}{r}* * \\
-0.679\end{array}$ \\
\hline
\end{tabular}

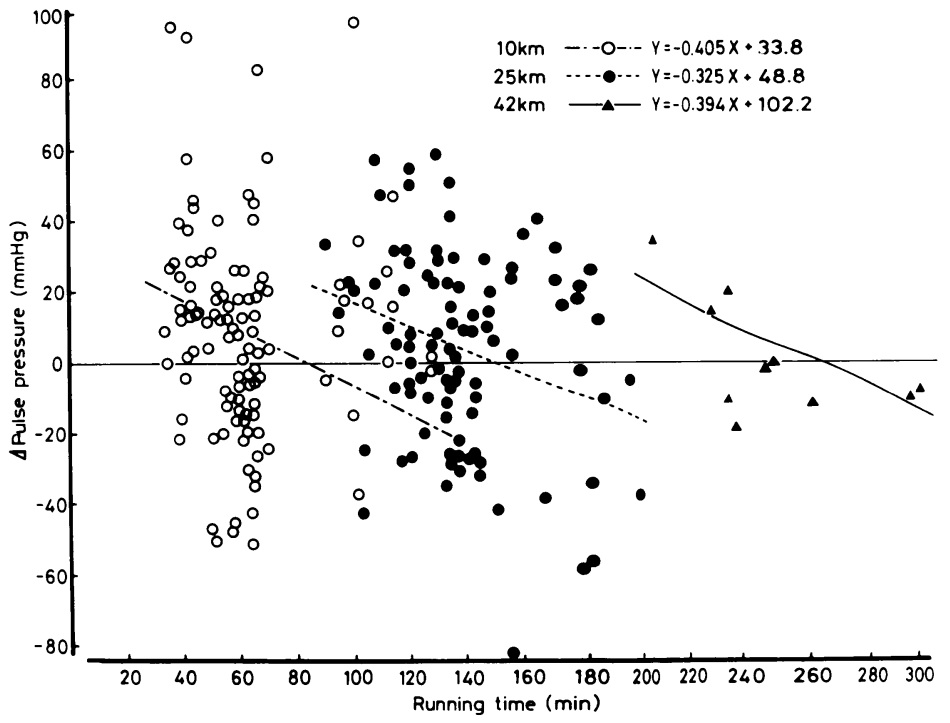

Fig. 4. Relationship between running time and difference of pulse pressure (Rest-After)

た。

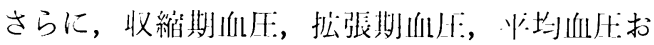

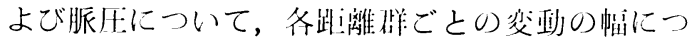
いてみると，脈压を除いて此離が瓝垴するに良っ て大きな低下゙を示した。

次に，乙れらの血压変動に関係をもっと考えら れる年命, 尘行時間, 走行前の血厌执よび脈在之 这行解後の血压差および脈压罒之の関係をみるた めに冬々の相関係数を求め表 2 に亦した。

その絬果，いずれの距離群とも起行的後空值と 作令との閒に有甞な相関は認められなかった。尘

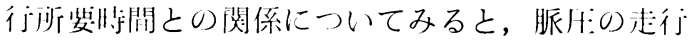
阙後值との開にいず扎の距離群とも有意な员の
相関が認められた。こ狆らり各被娩者ごとり值を プロットしたものが汹 4 である。10km および 25 $\mathrm{km}$ 群は，有总な相関ではあるが相閔係数む小さ く分布に大きな幅がみられた。 $42 \mathrm{~km}$ 任では，间 い绍の相関が珰められ，走行所要時間の長い者ほ よ゙起行後の脈出の低ドが大きいととを亦してい る。

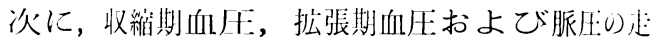
行解後着值とそれぞれの走行前值との関係をみる 之， $42 \mathrm{~km}$ 样の昖張期血庄之 $25 \mathrm{~km}$ 群の脈理に有 总な相関は認められなかったが，他の項目の相関 は，いずれも仍甞のものであった。瓯 5-a, b, c にこれらの各被駼者ごとひ值と各距離別の回㷌直 


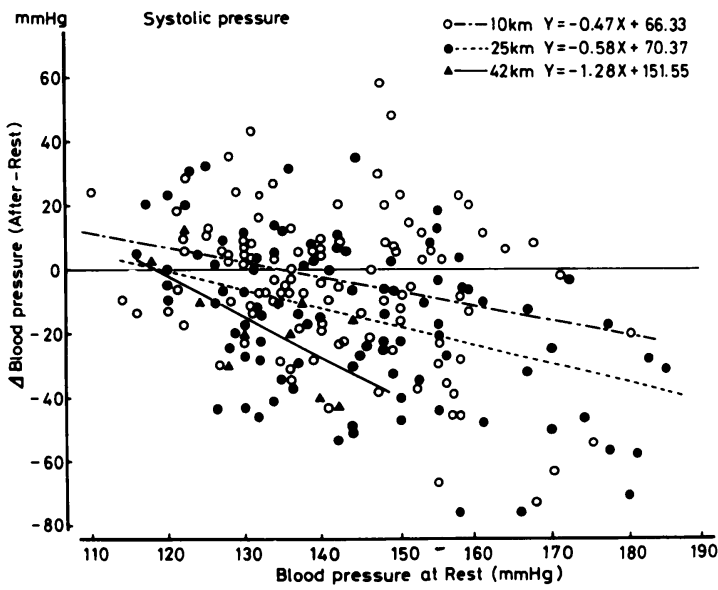

Fig. 5-a

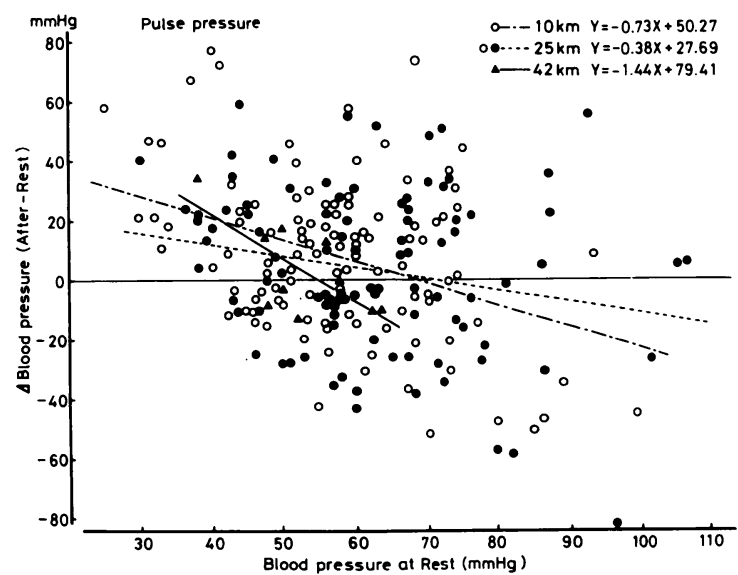

Fig. 5-c

線を示した。

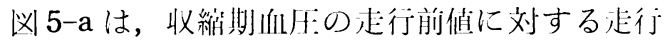
後の各被験者ごとの変動を示したものである。回

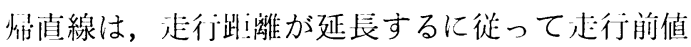
に対し走行後に低ドする，すなわち䧔性化が高度 になることを六している。特に，収綿期血压 160 $\mathrm{mmHg}$ 以上になると 23 人中 20 人が㓌性化し, そ の程度も大きい。

网 5-b は，同椂に拡張剘血厈:について示したも のである。仪綰期血圧と類似した倾们を示してお り，拡張剘价压 $90 \mathrm{mmHg}$ 以上では48人全具が䧔 性化しており，全被験者を合せると 207 人中 173 人が走行削に対し走行後低下しており，搪張期盀 压では陰性化の傾向が前いことを示している。

网 5-c は，脈压について同様に示したものであ

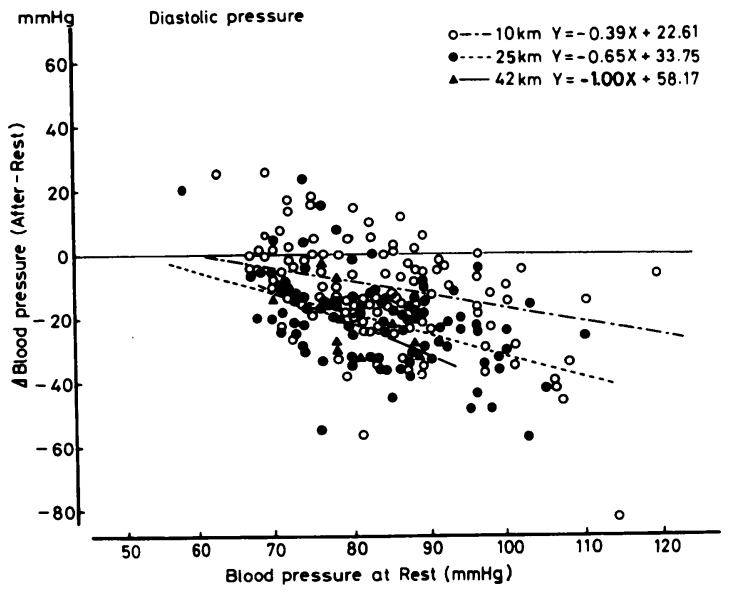

Fig. 5-b

Fig. 5-a, b, c. Relationship between rest and difference of systolic, diastolic and pulse pressure (Rest-After)

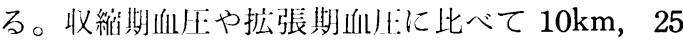
$\mathrm{km}$ 样では，顕著な差は認められなかった。

3. 走行前後の心電図について

怄 6 は，走行前後の心電四变化について示した ものである。特間肉于として $\mathrm{P}$ 波幅, $\mathrm{PQ}$ 間防， QTc および RR 閒㜔について示し，波高の因子 として P 波高, QRS 高, T 波高の 7 因子を杪準 唀導により， $\mathrm{RV}_{5}$ 波高は，胸部誘奨により記録し たものである。敦の斜線部分は，走行䏻を安静時 として，版間および波高の让常範明からの逸脱を 表わし，それ以外の部分は安静時の州常範囲を表

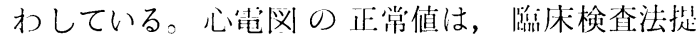

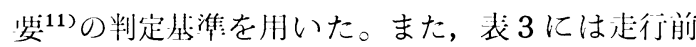

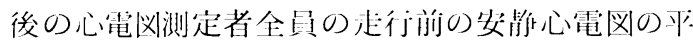
均值と愫準偏养について示した。 
Table 3. The mean values and $\mathrm{SD}$ at resting ECG

\begin{tabular}{c|c|c|c|c|c|c|c}
\hline \multicolumn{3}{c}{ Duration (sec) } & \multicolumn{4}{c}{ Voltage (mm) } \\
\hline $\mathrm{P}$ & $\mathrm{PQ}$ & $\mathrm{QTC}$ & $\mathrm{RR}$ & $\mathrm{P}$ & $\mathrm{QRS}$ & $\mathrm{T}$ & $\mathrm{RV}$ \\
\hline 0.10 & 1.02 & 0.40 & 1.02 & 1.22 & 13.30 & 3.05 & 20.35 \\
$(0.01)$ & $(0.03)$ & $(0.13)$ & $(0.11)$ & $(0.77)$ & $(3.73)$ & $(1.33)$ & $(6.43)$ \\
\hline
\end{tabular}

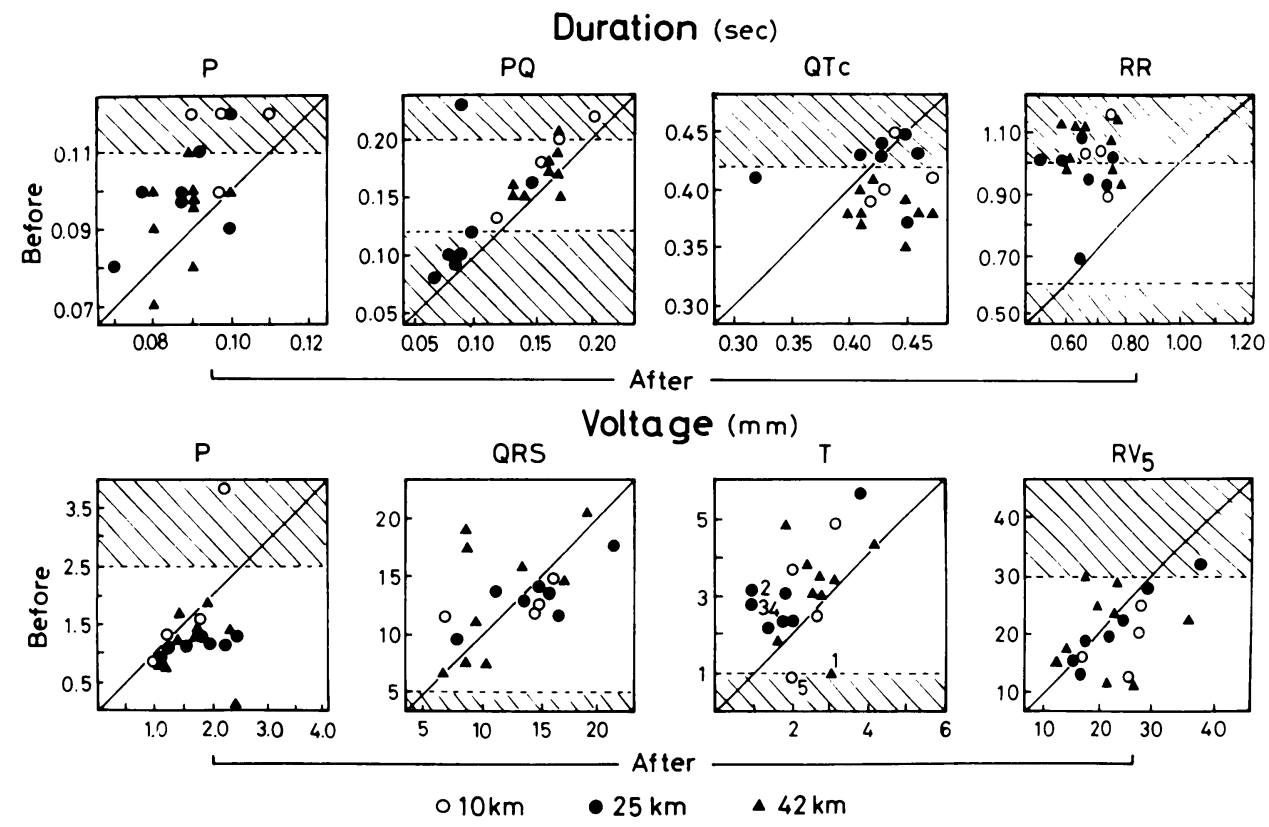

Fig. 6. Changes of ECG before and after running.

その絬果，炎消心记恼においては，QRS 波高 捄よびT波问の娍问，PQ 延長は少なく，むし万 $\mathrm{RR}$ 開隔 1.0 秒を起える洞性徐脈の者が 20 例中 12 例と比較的多くみられた。心筋の龙监仯心を示す ような ST, T波の変化は認められなかった。

边行的後の心電汹を比洨すると，P波幅は生行 能に対し走行後にやや短維する倾问にあるが，ほ とんよ゙変化はなかった。 $\mathrm{PQ}$ 開隔むほとんど变化 はなかったが， $25 \mathrm{~km}$ 群し1例で走行後著しく短 緗していた。また，边行润に $\mathrm{PQ}$ 延長を示してい た2例とも卡行後正常範朋にあった。QTcは， 走行㷙に刘し走行後にやや处长の似向にあり，山 でも $10 \mathrm{~km}$ 礁, $25 \mathrm{~km}$ 群でそれご机 1 例が大きな 延長を示し, 珎に $42 \mathrm{~km}$ 洋の 4 例で大きな延長を

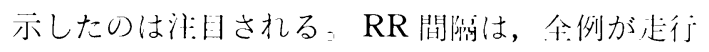

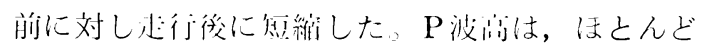
变化はなかった。ORS 波高もほとんよ゙变化して

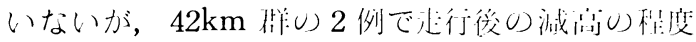

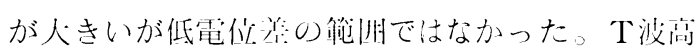
は，处行解後を比較する限り上行後やや減问似们

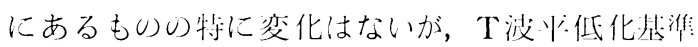
の $2 \mathrm{~mm}$ 以下抢よびR波间り $1 / 8$ 以下になる例を あげると，雨号 1 と 5 は小行䚘にT波平低化であ

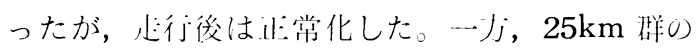
番号 2，3，4 は处行前は止常筑䎴にあったが，生 行後に柢低した。 $\mathrm{RV}_{5}$ 波茼は，ほとんよ゙变化は なかったが， $42 \mathrm{~km}$ 群と $25 \mathrm{~km}$ 踤でそれぞれ 1 例 ずつ增高を示した

\section{4. 走行中あるいはゴール後の卒倒者について}

表 4 は，起行师るいはゴール後众倒した者の そのときの身体状沈，片庄拉よび脈川:について示

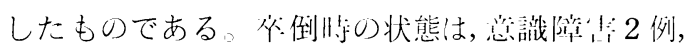

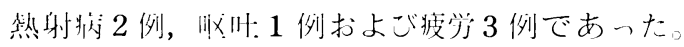

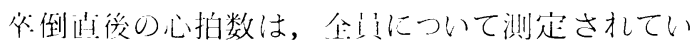


Table 4. Condition, blood pressure and pulse pressure of fainting runners

\begin{tabular}{|c|c|c|c|c|c|c|c|c|c|c|c|c|}
\hline & \multirow{2}{*}{ Age } & \multirow{2}{*}{ Conditions } & \multirow{2}{*}{$\begin{array}{c}\mathrm{HR} \\
\mathrm{A}\end{array}$} & \multicolumn{3}{|c|}{$\begin{array}{c}\text { Systolic pressure } \\
(\mathrm{mmHg})\end{array}$} & \multicolumn{3}{|c|}{$\begin{array}{l}\text { Diastolic pressure } \\
(\mathrm{mmHg})\end{array}$} & \multicolumn{3}{|c|}{$\begin{array}{l}\text { Pulse pressure } \\
(\mathrm{mmHg})\end{array}$} \\
\hline & & & & $\mathrm{R}$ & $\mathrm{A}$ & $A-R$ & $\mathrm{R}$ & A & $\mathrm{A}-\mathrm{R}$ & $\mathrm{R}$ & $\mathrm{A}$ & $A-R$ \\
\hline K. Y. & 45 & $\begin{array}{l}\text { Clouding of } \\
\text { consciousness }\end{array}$ & 166 & 122 & 112 & -10 & 80 & 90 & 10 & 42 & 22 & -20 \\
\hline S. K. & 46 & $\begin{array}{l}\text { Clouding of } \\
\text { consciousness }\end{array}$ & - & 137 & 134 & -3 & 84 & 94 & 10 & 53 & 40 & - I3 \\
\hline K. H. & 47 & Heat stroke & 110 & 130 & 130 & 0 & 73 & 80 & 7 & 57 & 50 & -7 \\
\hline M. S.* & 66 & Vomiting & - & 162 & 68 & -94 & 95 & 48 & -47 & 67 & 20 & -47 \\
\hline N. K. * & 67 & Fatigue & - & 159 & 90 & -69 & 90 & 60 & -30 & 69 & 30 & -39 \\
\hline T. K. & 71 & Fatigue & 110 & 155 & 150 & -5 & 77 & 90 & 13 & 78 & 60 & -18 \\
\hline Y.O. ${ }^{*}$ & 46 & Fatigue & 104 & 157 & 118 & -39 & 96 & 72 & -24 & 61 & 46 & -15 \\
\hline K. O. & 49 & Heat stroke & 140 & 134 & 108 & -26 & 81 & 52 & -29 & 53 & 56 & 3 \\
\hline
\end{tabular}

* : Hypertention

$\mathrm{R}:$ Rest (Before)

A : After falling down

ないが，每分 160 指， 140 抬と迎娚後としては高 い者も 2 例認められた。収維則血厓:は，ほとんど

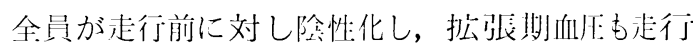
削值の高い者ほど䧔性化が著しいという网 5-a, b の結果之同栐の傾向を示した。さらに脈压は, $3 \mathrm{mmHg}$ 上昇した 1 例を除き全例で阾性化した。 特に, 収縮期血厈, 拡張期血㕅末よび脈压を通じ て被験者に*印を符した血压の高い者 3 例の䧔性 化が显著であった。中でも M.S. と N.K.は，収維 划仙肘がそ机ぞれ 94, 69mmHg 低下して 68,90 $\mathrm{mmHg}$ に落ちていた。

\section{5. 走行前後の体重の変化について}

㲸7は，走行前後の体重の変化について示した ものである。10km 群は, $1.24 \mathrm{~kg}(2.1 \%), 25 \mathrm{~km}$ 群は, $2.21 \mathrm{~kg}(4.0 \%$ および $42 \mathrm{~km}$ 群は, 2.69

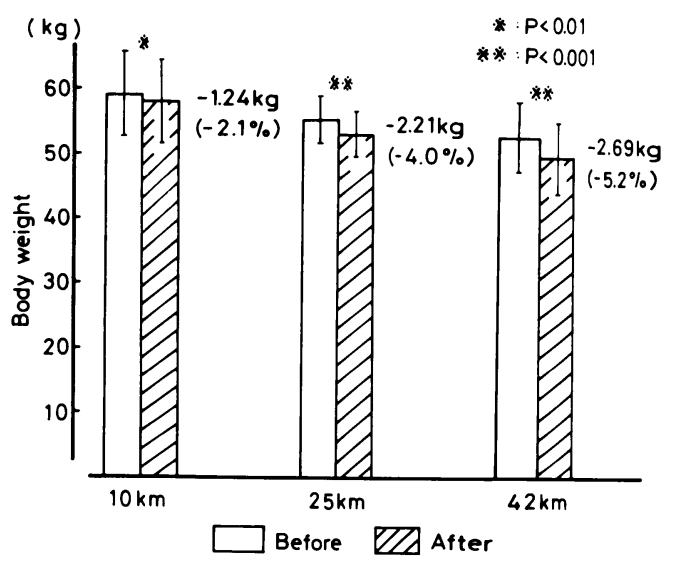

Fig. 7. Comparison of body weight between before and after running.

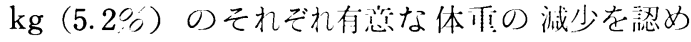
た。

\section{IV. 考察}

長趾離走においても，一般们には，边行践離が 短いほどスピードは速いと考えられるが，本結果 では短い距離の $10 \mathrm{~km}$ 群が最も遅かった。この結 果は,トレーニング経験の差によるあので, 経䮖 の盟窝な者が $25 \mathrm{~km}$ 造に参加し，大会のために仦 耖刃のトレーニングをし，あるいは経験の少ない 者が距朔への倠へがもてないために $10 \mathrm{~km}$ 走に多 く参版るという巾高年者や一般走者の特有の現 的のように思わ㧈る。いずれにせよ，乙の結果 は，各志者がそ机ぞ机の距離を条人の走能力の範 柬内で走行していたすのと考えら机る。

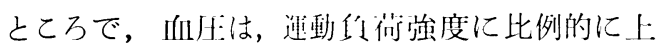
昇することが知ら机ている ${ }^{1)}$ 。村上ら ${ }^{18)}$ も，10000 $\mathrm{m}$ 走师の 400m 当りの所要猔間を出し, 将問が延 長すれば収縮期血压の上昇准は低下し，短維すれ ば上昇率が增大する，すなわち，尘行ペースの㜊 速つまり運動強度が走行中や走行直後の收絥期血 压の高低の主因となる可能性があると述べてい る。

一j，村上ら ${ }^{18)}$ は, $100 \mathrm{~m}, 400 \mathrm{~m}, 1500 \mathrm{~m}$ およ び $5000 \mathrm{~m}$ 走において，運動中に上昇した収縮剘 血压が走行中止後に走行前值を下回るような低下 を示し，てれを陰性相あるいは陰性化と呼び，走 行歫離が長くなるほど走行後早い時期に，しかも より深い阾性相の現わ机るととを報告している。 
しかしながら，乙れらは，運動時間が 1 時間以内 の走行距離についての報告であり，陰性相も走行 後平均 $8 \sim 25$ 分といった此較的長い回復期のあと に生じている。乙れに対し小川ら ${ }^{21)}$ 小野ら ${ }^{25)}$ は, $10 \mathrm{~km}$ および $25 \mathrm{~km}$ といった長い距離につい て検討し, 走行直後の血厯:の陰性化の生:じること を認めている。

本研究では, $10 \mathrm{~km}$ および $25 \mathrm{~km}$ 走にさらに 42 $\mathrm{km}$ のフルマラソンを加えて検討し，その結果血 压が走行後に走行前値より离い埸合あるいは陰性 化する場合の双方がみられたが，乙れを各被験者 ごとに検討すると，年令とは関係がなく，収縮期 血厈および昖侲剘血代之も走行前值の高い者ほど 走行後の陰性化が大きく，かつ $10 \mathrm{~km}, 25 \mathrm{~km}, 42$ $\mathrm{km}$ と走行距離が延辰するほよ゙除性化が大きいと いう紏果を得た。小川ら ${ }^{21)}$ も， $10 \mathrm{~km}$ より $25 \mathrm{~km}$ 群の才が安静水售が低くても陰性化する倾向が大 きいことを垫めている。これに対し，小野ら ${ }^{25)}$ は，高件令になるほど陰性化の大きいことを報告 している。乙れは，一般に高命者ほど血压が高く なる傾们があるので本結果とは矛盾しないように 考えられるが, 図 2 に示したように，本被験者 は，必ずしもトレーニングの効果とは言い切れな いが，高年令になってもさほよ゙佃压の上哠がみら れない。したがって，䍀圧の陰性相をみるとき年 令のみでなく走行前の安静值をより乐视したい。

脈压は，1回拍出量の指㥜之考えられており， ある程度までは連動強度に比例して增大すること が知られている2)。脈压について小川ら ${ }^{21)} は, 10$ $\mathrm{km}$ 群では走行後に上算し， $25 \mathrm{~km}$ 群では低下し たと報售しているが, 本結果では, $10 \mathrm{~km}$ および $25 \mathrm{~km}$ 群では明確な桨は認められず， $42 \mathrm{~km}$ 群で は走行スピードの速い者は, 走行前より高く, 遅 い者は低下していた（図 4 ）。また， $25 \mathrm{~km}$ 群でも 沂装特間の 150 分を超える者では走行前に対する 低下の度合の大きい者が多く認められており，25 $\mathrm{km}$ 以上の距離での所要時閒のかかる者にとって は脈压への影響が大きいものと若えられる。

血压の調節には，神経性因子と体液性因子が考 えられる。このような長距離走後の血压の陰性化 を生じる原因としては, 未梢血管の搪㖘, 発汗な どの脱水現象に伴う血漿量の減少, 1 回拍出量の 減少, 緊張による走行前值の上早などが考えられ
る。

Ekelund $^{5)}$ は, 1 時間の白転車運動を行った際 に, 運動開始後10分目を基準として，それ以降に 1 回拍出量と血压が漸時低下し, 心拍出量は定常 状態にあり，心拍数は漸增したことを認めてい る。また, Saltin ら ${ }^{28)}$ も, 比較的長時間（30分以 上）の運動を断続的に約 $\mathbf{3}$ 時間行なわせて運動中 に 1 回拍出量と血压の低下を認めている。また, Hartley ら はあるが，運動強度が高くなるにつ机て木梢血管 抵抗が低下することを認め， Grimby ら ${ }^{6)}$ も，中 等度の運動でしばしば動脈厈が经度に低下し，そ の主因は，皮虚血管の昖張であると述べている。 さらに, Buchberger)は，16〜54才の男女の 100 $\mathrm{km}$ 少行中の生理的変化について報告し，血压は 歩行後に年份が高いほよ゙，また，歩行前値が高い ほど低下し，そのとき体重の平均 $2.0 \mathrm{~kg}$ の有意な 低下があったととを認めている。

本研兊の結果であ, 走行前後の体重は, 走行践 離が延辰するほど体重の隇少が大きくなることを 涊めた。これらの体重減少の主因は, 血液内の水 分が外に们っては発汗と長時間の換気によって減 り, 内では筋組織内へ漏出するためであると考え

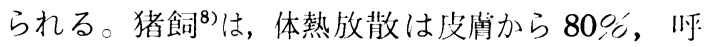
気から $20 \%$ と述べ，さらに多量の発汗では 1 壮势開 に $1.5 l$ の汗が出ると述べており, 発汁による体 液の減少の激しさを指摘している。したがって， 体重減少つまり脱水も 1 回拍出量や䍀厅:低下の媭 因であることが示唆される。

ところで, 取大運動時には测交感神経の心臓支 配はほとんど行なわ机ないとされている27)が，村 上ら ${ }^{17)}$ は, 運動で血怰リクレイン椂物質濃度の 增大があり，また，カリクレイン様物質は迷走神 経刺激により分泌の增大をみることから，少なく とも運動持続で疫僵状態に陷れば副交感神経緊張 の增大も来たされる可能性があり，すなわち，体 液性因子による運動時の降压効果の可能性のある ことを示唆している。

さらに, 四 5-a, bに示すように収縮期血厌: 160 $\mathrm{mmHg}$ 以上, 拡張期血压 $90 \mathrm{mmHg}$ 以上の者に おいて，また，卒倒者のうち高い血厌の者にみら 机るように安静値の高い者ほど陰性化が大きいと いうことは，血圧の高い場合に認められる血得内 
臂の硬化などの血管壁の弾性に関する物理的特性 も運動後の血压除性化の一因をなすものと考えら れる。

運動後の心電図所見については，一定の見解は なく, 種々の変化が認められている。PQ 間隔に

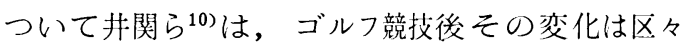
あるが短縮例が多いととを報告し，北村ら ${ }^{13)}$ は, 水泳選手の全力泳前後の心電図の検討で大多数は 負荷直後の頻脈時には PQ 間隔は短維するが，少 数例ではむしろ延長するととを認め, $\mathrm{PQ}$ 延長の すべてが Vagotony とは解しがたく，一部心筋そ のあのの器質的変化の存在を考慮せざるを得ない と述べている。本結果では, $\mathrm{PQ}$ 閒隔は, 変化が ないか短縮する倾向にあった。QTcについて井 関ら ${ }^{10)}$ は, 短縮例の多いととを報告しているが, 住吉ら ${ }^{31)}$ は, $100 \mathrm{~m}$ の全力の水泳直後に延長例の 多いてとを認めており，本結果でも延長例が多 く, 特に $42 \mathrm{~km}$ 群で 9 例中 4 例は大きな延長を示 した。その他に注目されるのは，一般に T 波高 は，迺動後增高すると報告されている ${ }^{1031)}$ が，本 結果では, 減高傾向を示し, 特に走行後平低化す る例が $25 \mathrm{~km}$ 群に 3 例みられた。このような 平低化の原因として心筋虚血, 低カリウム血症拉 よび作業にとむなう自律神経関与による機能的 $\mathrm{T}$ 平低化などが考えられるが，本結果では，発汗に よる電解質変化によるものと推察される。

また，本被験者には認められなかったが，松本 ら ${ }^{15)}$ は, 中高年者の長距離起打いて競技後の心 虚血反応の出現が40才代で51例中 3 例 $(5.8 \%)$, 50 才代で 59 例巾 9 例 (15.1\%)，60才代で 70例巾 20 例 $(28.6 \%), 70$ 才代以上:で 21 例中 6 例 (28.6 兑）に認的れたと報告し，長距離走前の健康管; 理の荘を強調している。

走行中あるいはゴール後不倒した者の状況につ いては様々の状態が認められるが，血圧について みると莝倒者 8 人中 3 人が収縮期 血压: $157 \mathrm{~mm}$ $\mathrm{Hg}$ ，拡張期血圧 $90 \mathrm{mmHg}$ 以上であり，さらに 众倒後の血压および脈圧の低下が著しい点を考虑 するとき，ここに至る原团は究明しがたいが，25 $\mathrm{km}, 42 \mathrm{~km}$ といった長い距離を 2 時間， 3 時間あ るいは 4 時間もの時間を要して走行するての種の 大会の発汗などによる体液，血庄:および心電図の 変動からみた循環機能に及ぼす影響について十分
考虑し，中高年者のランニングの本来の目的を失 なわないように注意する必要があろう。

\section{V. 要 約}

40 87才の男子中高年者 235 人について $10 \mathrm{~km}$, $25 \mathrm{~km}$ および $42 \mathrm{~km}$ 走における走行前後の血压, 心電図および体重の変動について测定し，さらに 走行中あるいはゴール後丛倒した者の血压につい て測定し，長距離走が中高年者の循環機能に及ぼ す影響について検討した。その絬果を要約すると 以下のとおりである。

1）走行前後の血压は，収縮期血压および搪張 期血圧とも走行前值の高い者ほど，また，走行距 離が $10 \mathrm{~km} ， 25 \mathrm{~km}$ および $42 \mathrm{~km}$ と延長するほど 高度の陰性相を示した。

2）走行前後の脈生も，走行前值の高い者ほど 陰性化する傾向がみられたが， $42 \mathrm{~km}$ 群を除いて 距離による缮は認められなかった。

3）走行前後の心電困の比較では, 走行後 $\mathrm{PQ}$ 閒隔は短縮傾们に，QTc は延辰傾向にあり，特 に $42 \mathrm{~km}$ 群において 9 例中 4 例に高度の延長が認 められた。また， T波高は減高傾向にあり， $25 \mathrm{~km}$ 群で 7 例中 3 例に平低化が認められた。

4）走行による卒倒者の血厈および脈厈の変動 では陰性化が著明であり，特に血压の高い者にお いてきわわて著しい低下を示した。

5）走行後の体重は，走行前に刘して $10 \mathrm{~km}$ 群 が $1.24 \mathrm{~kg}, 25 \mathrm{~km}$ 群が $2.21 \mathrm{~kg}$ および $42 \mathrm{~km}$ 群 が $2.69 \mathrm{~kg}$ の有意な低下を示し，IIII厈隍性化の主 因が発汗によるものと考えられた。

以上の結果, 中高年者の長距離走は距離が延長 するほど,また，项压の高い者ほよ゙その循環機能 に大きな变動を来す点が师らかになった。

終りに，本研劣に際し特別ので配虑とご協力を載 いた日本タートル協会々長・岡田英夫氏ならびに関

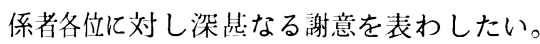

なお，本論文の要旨は，第32回日本体力医学会総 会（青森，1977）において発表した。

（受付 昭和 55 年 12 月 26 日）

\section{文}

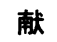

1) Åstrand, I. (1965) : Blood pressure during physical work in a group of 221 women 
and 48-63 years old. Acta Med. Scand., 178(1), 41-46

2) Åstrand, P-O., Cuddy, T.E., Saltin, B., and Stenberg, J. (1964) : Cardiac output during submaximal and maximal work. J. Appl. Physiol., 19(2), 268-274

3) Barry, A. J., Daly, J. W., Pruett, E.D.R., Steinmetz, J.R., Page,H.F., Birkhead, N.C., and Rodahl, K. (1966) : The effects of physical conditioning on older individuals. I. Work capacity, circulatory-respiratory function, and work electrocardiogram. J. Geront., 21, 182-191

4) Buchberger, V., Novozamsky, J. V., und Kvapilik, J. (1972) : Physiologische beurteilung des 100-km-marsches. Sportmedizin, 23(6), 113-117

5) Ekelund, L.G. (1966) : Circulatory and respiratory adaptation during prolonged exercise in supine position. Acta Physiol. Scand., 68, 382-396

6) Grimby, G., and Nilsson, N.J. (1963): Cardiac output during exercise in pyrogen-induced fever. Scand. J. Clin. Lab. Invest., 15(suppl. 69), 44-61

7) Hartley, L.H., Grimby, G., Kilbom, A., Nilsson, N.J., Åstrand, I., Bjure, J., Ekblom, B., and Saltin, B. (1969) : Physical training in sedentary middle-aged and older men. III. Cardiac output and exchange at submaximal and maximal exercise. Scand. J. Clin. Lab. Invest. 24, 335-344

8）猪飼道犬（1969）：スポーツ突兴人川， p. 170171，南山售，来宗

9）伊藤 稳, 宮田淌之, 万帅非人, 熊本水赖, 伊 藤一柆, 武部否吉, 八木 保, 山下謙得, 中村 策太郎(1973)：歩行トレーニングによる中高件 者の全身持久性の们上について。体青科管， 1， 134-143

10）井関敏之, 住吉 薰, 住吉美智子, 高田昌広, 神了昭典, 前田如矢, 山田耕司, 失野敏夫, 大 谷 遷, 宮崎喜重郎, 汇村止信, 東 朋嗣, 島 田瑞夫，木永暎代，加藤宗男(1961)：ゴルフ競 技後の心雪四・血厌:について。体力科学, 10, 173

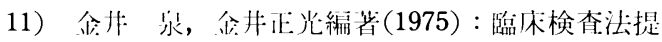

要第27版，循環機能検查法，金原出版，身宗

12) Kasch,F.W., Phillips, W.H., Carter, J.E.L., and Boyer, J. L. (1973) : Cardiovascular changes in middle-aged men during two years training. J. Appl. Physiol., 34(1), 53 $-57$

13）北村和人，小川 炎，山帠克麿，瀬戸厚子，渡 迅 哲，上忖吕秀(1961)：スポーツ心歲につい

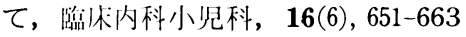

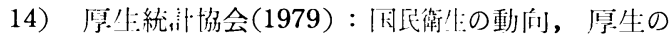
指满: - 特集, $26(9)$

15）松本战位，松本否俊，仵藤 公(1976)：スポー ツ殿手の心電网变化について。体力科兴， 25 (1), 16-27

16）飯堟鉄雄，日丸折也，永田晟，中西光碓，岩 崎義正，礒川业教(1975)：日本人の体力惦準值 (第 2 版)，不昧掌出版，東宗

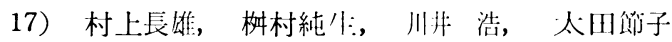
(1972)：カリクレイン・キニン系の生押们意 義. 日本生理誌, 34, 522

18）村上医雄，川井 浩，太田節子，高島恬助，计 木 柾, 佐藤陽占, 令敷下稔, 岸野悦直, 水田 幐愽，中田健次蚛，武部吉秀(1975）：身体遇動 の最高向厅に及ぼす影響。体力科学, $24(1), 11$ $-24$

19) Naughton, J., and Nagle, F. (1965) : Peak oxygen intake during physical fitness program for middle-aged men. - Measurement of changes by laboratory and field testing. J. Am. Med. Ass., 191(11), 899-901

20）日本タートル協会(1976)：䟢中高年过者スポ

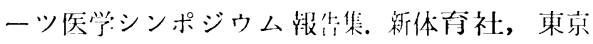

21）小川新吉，线野勝し，古田盖们，藤牧利昭，小

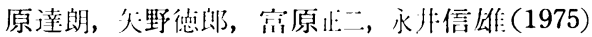
：中高年長距滩处者の尘理機能一一特に，血压 ・心電図・尿・形態について一。束京教育人 学スポーツ研究所㪕, 13,1-14

22）小川新吉, 古田缮伦, 小原達朗, 大神八太趴 (1976) : ランニングトレーニングの中高件者の

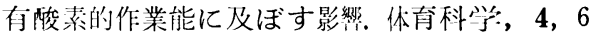
$-12$

23）小野三嗣(1972)：健康をむとめて・老年:期, 不 昧堂出版, 東宗

24）小野三嗣(1978)：遇動の生理科学, 朝食書怎, 来察

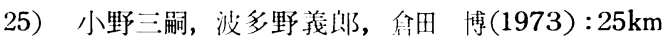


競走が中高什：考の血压及び尿所少に及ぼす影 響。体力科学, 22, 81-84

26) Pollock, M.L., Miller, H.S., Janeway, R., Linnerud, A.C., Robertson, B., and Valentino, R. (1971) : Effects of walking on body composition and Cardiovascular function of middle-aged men. J. Appl. Physiol. 30 (1), 126-130

27) Robinson, S., Pearcy,M., Brueckman,F.R., Nicholas, T.R., and Miller, D.I. (1953): Effects of atropine on heart rate and oxygen intake in working man. J. Appl. Physiol., 5, 509-512

28) Saltin, B., and Stenberg, J. (1964) : Circulatory response to prolonged severe exercise. J. Appl. Physiol., 19(5), 833-838

29) Saltin,B., Hartley, L.H., Kilbom, A., and Åstrand, I. (1969) : Physical training in sedentary middle-aged and olde men.Oxygen uptake, heart rate, and blood lactate concentration at submaximal and maximal exercise. Scand. J. Clin. Lab. Invest., 24, 323-334

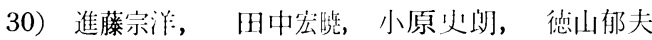
(1974) : 中高作者の自転車エルゴメーターによ

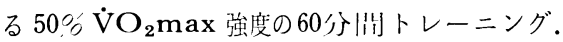
体䏍科少，2，139-152

31）住南藻，住吉美智子，前田如欠，山田耕司，

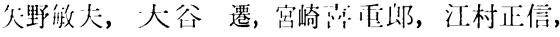
島田瑞夫，木永暎代，非闺政之，東 朋嗣 (1961)：水泳中の心電帆兴的検討. 体力科学， 10,175

31) Wilmore, J.H., Gilandola, R.N., Katch, F.I., and Katch, V.L. (1970) : Physiological alternation resulting from a 10 -week program of jogging. Med. Sci. in Sports, 2(1), 7-14 